\title{
Gamakamide-E, a Strongly Bitter Tasting Cyclic Peptide with a Hydantoin Structure from Cultured Oysters Crassostrea gigas
}

\author{
Jong Soo Lee ${ }^{1}$, Masayuki Satake ${ }^{2 *}$, Yoichi Horigome ${ }^{2}$, Yasukatsu Oshima ${ }^{2}$ and Takeshi Yasumoto ${ }^{2}$ \\ ${ }^{1}$ Department of Seafood Science and Technology, Institute of Marine Industry, Gyeongsang National University, Tongyeong 650-160, \\ Korea \\ ${ }^{2}$ Graduate School of Agricultural Science, Tohoku University, 1-1 Tsutsumidori-Amamiya, Aoba-ku Sendai, Miyagi 981-8555, Japan
}

\begin{abstract}
A new cyclic peptide (six-membered amino acid), gamakamide-E (L-Leu-L-Met (SO)-L-Me-Phe-L-Leu-D-Lys-L-Phe), was isolated as a strongly bitter tasting compound from cultured oysters, Crassostrea gigas. The molecular formula of $\mathrm{C}_{43} \mathrm{H}_{61} \mathrm{~N}_{7} \mathrm{O}_{8} \mathrm{~S}$ was deduced from high resolution fast atom bombardment mass spectrometry (HR FAB-MS) $\left([\mathrm{M}+\mathrm{H}]^{+} \mathrm{m} / z\right.$ 836.4356 $\left.\Delta=-2.4 \mathrm{mmu}\right)$. Its unique structure including a hydantoin structure was firstly elucidated by nuclear magnetic resonance (NMR) analysis. Stereochemistries of constituent amino acids were determined by chiral high performanced liquid chromatography analysis of natural and synthesized peptides.
\end{abstract}

Key words: Oyster, Crassostrea gigas, Gamakamide-E, Cyclic peptide, Marfey analysis, Bitter taste

\section{Introduction}

Oyster is an important bivalve species in the shellfish industry in Korea due to its high nutritional value and good taste. However, many reports have indicated their deterioration in quality including taste. Also the quality varies depending on the cultivation conditions, such as the quantity or species of feed planktons or water quality. Color changes in oysters, such as greening (Kimura, 1969) and red (Hata et al., 1982) and yellowish (Hata et al., 1987) coloration, are presumed to originate from feed plankton. Also, Hatano et al. (1990) reported an unacceptable taste and coloration of oysters in Japan. Moreover, Parry et al. (1989) reported the bitter taste of cultured oysters during a bloom of the diatom, Rhizosolenia chunii in southern Australia. However, the compound causing the bitter taste was not identified. Despite the lack of official reports on quality problems, shellfish farmers relate stories of multiple annual quality deteriolations of cultured shellfish including oysters. Therefore, it is necessary to elucidate the reasons underlying this phenomenon to ensure quality control and food hygiene.

In Korea, Lee (1995) first reported bitter-tasting oysters cultured in Gamak Bay on the southern coast between November 1989 and January 1990. Smoked and boiled-canned oysters produced by using the oysters collected at the same location also tasted bitter. Although no report of illness followed the consumption of these bitter oysters, the taste seriously damaged the local oyster industry. The incident prompted us to elucidate the structure of the bitter compound. From oysters collected during that event, five bitter tasting compounds with peptidic natures tentatively named gamakamides A-E (derived from the name of Gamak Bay), were isolated (Lee, 1995). We aimed to report the structure of gamakamide-E .

\section{Materials and Methods}

\section{Materials}

Open Access http://dx.doi.org/10.5657/FAS.2012.0015

This is an Open Access article distributed under the terms of the Creative Commons Attribution Non-Commercial License (http:// creativecommons. org/licenses/by-nc/3.0/) which permits unrestricted non-commercial use, distribution, and reproduction in any medium, provided the original work is properly cited.
Received 6 December 2011; Revised 17 January 2012; Accepted 8 February 2012

*Corresponding Author

E-mail: msatake@chem.s.u-tokyo.ac.jp 
Bitter-tasting oyster Crassostrea gigas, were collected during December, 1989, at a farm in Gamak Bay, Yousu Province, Korea, and the smoked and the boiled-canned oysters were provided by a local canned food company in Tongyeong.

\section{Spectroscopic analysis}

The nuclear magnetic resonance (NMR) spectra were measured using a JEOL GSX-400 (Jeol, Tokyo, Japan), and Varian Unity INOVA 600 (Palo Anto, CA, USA) in $\mathrm{D}_{2} \mathrm{O}, \mathrm{CD}_{3} \mathrm{CN}$ and $\mathrm{CD}_{3} \mathrm{OD}$. High-resolution (HR) and low-resolution fast atom bombardment mass spectrometry (FAB-MS) spectra were measured with a JEOL JMS $303 \mathrm{HF}$ spectrometer (Jeol, Tokyo, Japan) and JEOL JMS 700 spectrometer (Jeol). Electrospray ionization mass spectrometry (ESI-MS) spectra were measured with a Finnigan Mat TSQ-700 spectrometer (San Jose, CA, USA). Circular dichroism (CD) spectra were recorded on a JASCO J-720 spectropolarimeter (Jasco, Tokyo, Japan). Optical rotations were measured with a DIP-370 spectrometer (Jasco).

\section{Isolation of gamakamide-E}

Frozen raw $(1 \mathrm{~kg})$, smoked-canned $(10 \mathrm{~kg})$ and boiledcanned $(17 \mathrm{~kg})$ oysters were extracted with acetone three times. After evaporating off the acetone, the extract was partitioned between $\mathrm{MeOH}-\mathrm{H}_{2} \mathrm{O}(8: 2)$ and hexane. A bitter residue obtained in the $\mathrm{MeOH}-\mathrm{H}_{2} \mathrm{O}(8: 2)$ layer was next partitioned between $\mathrm{CHCl}_{3}$ and $\mathrm{H}_{2} \mathrm{O}$. The organic fraction was evaporated, dissolved in $\mathrm{CHCl}_{3}-\mathrm{MeOH}$ (1:1), and passed through an alumina column (ICN Biomedicals, Seven Hills, NSE, Australia). The column was washed with $\mathrm{CHCl}_{3}-\mathrm{MeOH}(1: 1)$ and the bitter compound was eluted with $1 \% \mathrm{NH}_{4} \mathrm{OH}-\mathrm{MeOH}(1: 1)$. The residue was chromatographed on a silica gel column (Merck, Darmstadt, Germany) with $\mathrm{CHCl}_{3}, \mathrm{CHCl}_{3}-\mathrm{MeOH}$ (9:1) and $\mathrm{CHCl}_{3}-\mathrm{MeOH}(1: 1)$ and the bitter compound was detected in the second eluate. The bitter substances were further purified on a Toyopearl HW-40 column (Toso, Tokyo, Japan) with $\mathrm{MeOH}-\mathrm{H}_{2} \mathrm{O}(7: 3)$, The constituents were dissolved in $\mathrm{MeCN}-\mathrm{H}_{2} \mathrm{O}(45: 55)$ and passed through a Fuji Gel ODS column (Fuji Chemical, Tokyo, Japan) with the same solvent. Further high performance liquid chromatography (HPLC) purification was performed on a Develosil ODS-7 column $(10 \times$ $250 \mathrm{~mm}$; Nomura Chemicals, Tokyo, Japan) with $\mathrm{MeCN}-\mathrm{H}_{2} \mathrm{O}$ (45:55) and on an Asahipak ODP-50 column $(0.8 \times 250 \mathrm{~mm}$; Showa Denko, Tokyo, Japan) with $\mathrm{MeCN}_{-} \mathrm{H}_{2} \mathrm{O}$ (45:55, yield: $0.0002 \%$ against to the raw oyster).

\section{Acid hydrolysis and Marfey analysis}

Purified gamakamide-E $(0.1 \mathrm{mg})$ was hydrolyzed with 6 $\mathrm{N} \mathrm{HCl}$ in an evacuated tube by heating at $110^{\circ} \mathrm{C}$ for $26 \mathrm{~h}$. After cooling to room temperature, the reaction mixture was evaporated at $50^{\circ} \mathrm{C}$ in vacuo. The resulting acid hydrolysate was mixed with $20 \mu \mathrm{L}$ of $1 \%$ 1-fluoro-2,4-dinitrophenyl5-L-alanine amide (FDAA) solution in acetone and $10 \mu \mathrm{L}$ of $0.1 \mathrm{M} \mathrm{NaHCO}_{3}$, and heated at $37^{\circ} \mathrm{C}$ for $1 \mathrm{~h}$. After cooling to room temperature the reaction mixture was neutralized with $10 \mu \mathrm{L}$ of $0.1 \mathrm{~N} \mathrm{HCl}$. After removing of the solvent, the reaction mixture was dissolved in MeOH. HPLC analysis was accomplished by using a Cosmosil 5C18-AR (4.6 × $250 \mathrm{~mm}$; Nacalai Tesque, Kyoto, Japan) column with gradient elution by altering ratios from $1 \% \mathrm{AcOH}-\mathrm{MeCN}$ to $79: 21$ to $73: 27$ (85 $\mathrm{min})$, to $64: 36$ (105 $\mathrm{min}$ ) and to $27: 73$ (150 $\mathrm{min})$. The flow rate maintained at $1.0 \mathrm{~mL} / \mathrm{min}$ and UV detection was done at 340 $\mathrm{nm}$. In Marfey analysis, gamakamide-E gave L-Met (55 min; D-Met, $88 \mathrm{~min}$ ), L-Leu (96 min; D-Leu, $112 \mathrm{~min}$ ), L- $N$-Mephe (100 min; D- $N$-Mephe, $102 \mathrm{~min}$ ) and racemic Phe-D-Lys dipeptide (108 and $111 \mathrm{~min}$; Phe-L-Lys, 109 and $110 \mathrm{~min}$ ).

\section{Results and Discussion}

\section{MS spectra of gamakamide-E}

From frozen and canned oysters, gamakamide-E was isolated as a colorless amorphous solid $\left([\alpha]_{\mathrm{D}}^{20}-77.8^{\circ}[\mathrm{c} 0.036\right.$, $\left.\mathrm{CH}_{3} \mathrm{OH}\right]$ ) after several chromatography steps (Lee, 1995). Amino acid analysis revealed two units of leucine (Leu) and one methionine (Met). The positive ion FAB MS/MS of gamakamide-E (Fig. 1) gave a molecular ion peak $[\mathrm{M}+\mathrm{H}]^{+}$at $\mathrm{m} / \mathrm{z} 836.5$ and many fragment ion peaks such as $[\mathrm{M}-\mathrm{Leu}]^{+}$at $m / z$ 723.5, [M - Leu - NMePhe] $]^{+}$at $m / z$ 562.4, [Phe + Lys + $\mathrm{Leu}^{+}$at $m / z 415.4$ and $[\mathrm{Phe}+\mathrm{Lys}]^{+}$at $m / z$ 302.3, respectively. An intensive peak appeared at $m / z 772.6$ corresponding to [M - $\left.\mathrm{SOCH}_{3}\right]^{+}$, suggesting the existence of methionine sulfoxide $[\mathrm{Met}(\mathrm{O})]$ in the molecule.

Conversion of L-Met(O) (Sigma, St. Louis, MO, USA) to L-Met by acid hydrolysis was confirmed by ESI MS and HPLC. Therefore, the existence of $\operatorname{Met}(\mathrm{O})$ in the molecule was confirmed. The molecular formula of $\mathrm{C}_{43} \mathrm{H}_{61} \mathrm{~N}_{7} \mathrm{O}_{8} \mathrm{~S}$ was deduced from HR FAB-MS $\left([\mathrm{M}+\mathrm{H}]^{+} m / z 836.4356 \Delta=-2.4\right.$ $\mathrm{mmu}$ ).

\section{Planar structure of gamakamide-E}

Analysis of 2D NMR spectra, COSY, TOCSY, HSQC and heteronuclear multiple bond correlation (HMBC), allowed the complete assignment of these three amino acids as well as the assignment of signals for $\mathrm{N}$-methylphenylalanine ( $\mathrm{N}$-Mephe), phenylalanine (Phe) and lysine (Lys). The ${ }^{1} \mathrm{H}$ NMR spectrum (Fig. 2) in $\mathrm{CD}_{3} \mathrm{CN}$ displayed two sets of signals around methionine sulfoxide at a 1:1 ratio.

This ratio was unaffected by temperature alteration, indicating that the two sets of signals did not arise from conformational changes, but from stereoisomers of sulfoxide in Met (O). In the ${ }^{13} \mathrm{C}$ NMR spectrum (Fig. 3), a ureido carbon was detected at $156.7 \mathrm{ppm}$. The remaining of 42 carbons were as- 
signed to the amino acid residues.

All these data about the ${ }^{1} \mathrm{H}$ NMR and ${ }^{13} \mathrm{C}$ NMR summarized on the Table 1.

Sequencing of amino acids was mainly accomplished by
HMBC experiments (Fig. 4). Correlations between NH protons and the $N$-methyl group with neighboring carbonyl carbons were observed between 6-NH/C7, 8-NH/C13, Me22/ C23, 24-NH/C28, and 29-NH/Cl (Fig. 5).

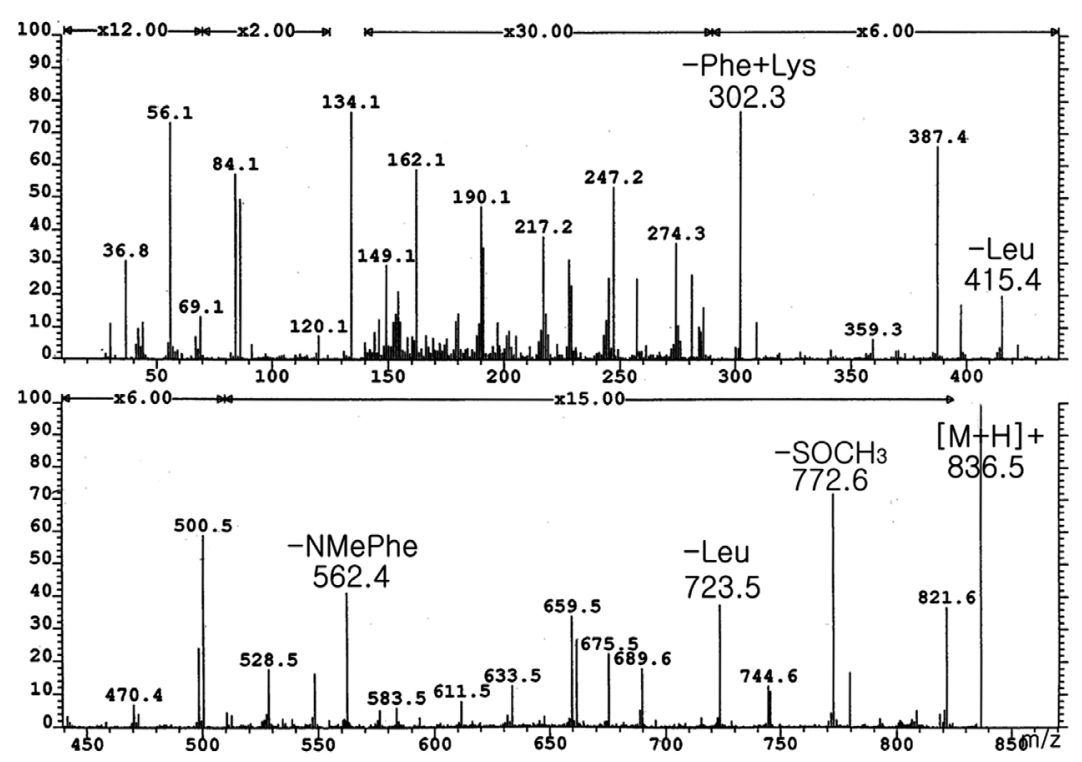

Fig. 1. Mass spectrometry-mass spectrometry (MS/MS) spectrum of gamakamide-E (fast atom bombardment positive mode).

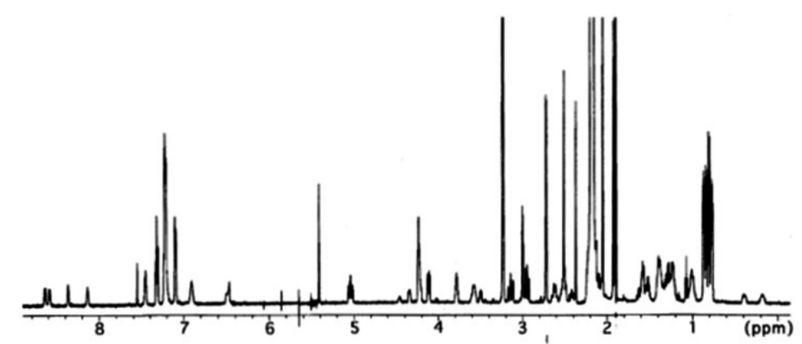

Fig. 2. Proton nuclear magnetic resonance ('H NMR) spectrum of gamakamide-E $\left(600 \mathrm{MHz}, \mathrm{CD}_{3} \mathrm{CN}\right)$.

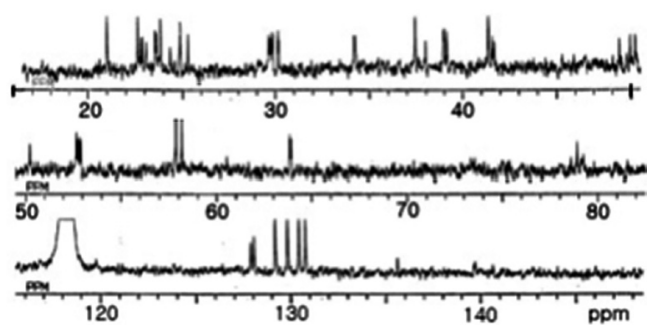

Fig. 3. Carbon nuclear magnetic resonance $\left({ }^{13} \mathrm{C} N M R\right)$ spectrum of gamakamide $\mathrm{E}$.

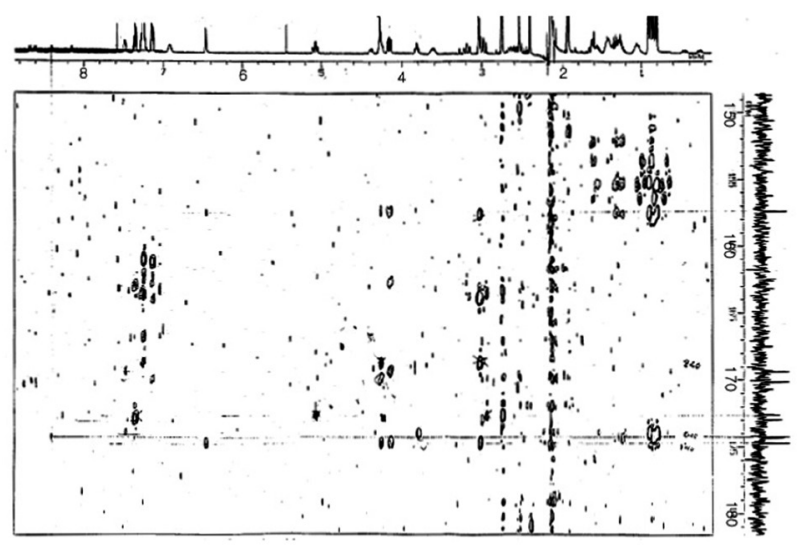

Fig. 4. Heteronuclear multiple bond correlation (HMBC) spectrum of gamakamide-E.

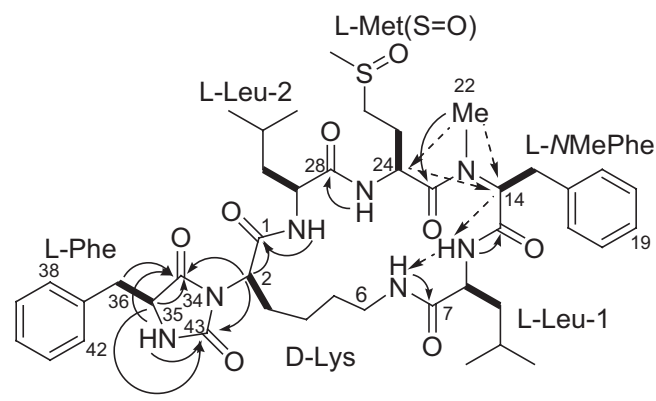

Fig. 5. Assignment of partial structure for gamakamide $\mathrm{E}$ by $\mathrm{HMBC}(\rightarrow)$ and $\mathrm{NOE}(---)$ spectra. $\mathrm{HMBC}$, heteronuclear multiple bond correlation; NOE, nuclear overhauser effect. 


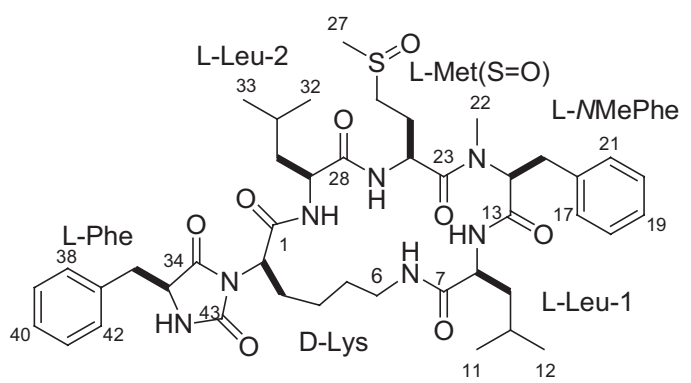

Fig. 6. Structure of gamakamide-E.

Table 1. Assignment of ${ }^{1} \mathrm{H}$ and ${ }^{13} \mathrm{C}$ NMR spectra for gamakamide-E (600 $\mathrm{MHz}, \mathrm{CD}_{3} \mathrm{CN}$ )

\begin{tabular}{|c|c|c|c|c|}
\hline & Position & ${ }^{1} \mathbf{H}(\mathbf{p p m})$ & $J / H z$ & ${ }^{13} \mathrm{C}$ (ppm) \\
\hline \multirow{7}{*}{ Leu-1 } & $\alpha \mathrm{CH}$ & 4.24 & $\mathrm{~m}$ & 52.2 \\
\hline & $\mathrm{BCH}_{2}$ & 1.57 & $\mathrm{~m}$ & 40.8 \\
\hline & $\gamma \mathrm{CH}$ & 1.38 & $\mathrm{~m}$ & 24.5 \\
\hline & $\delta \mathrm{CH}_{3}$ & 0.84 & d 6.2 & 23.1 \\
\hline & & 0.81 & d 6.2 & 20.1 \\
\hline & $\mathrm{NH}$ & 8.66 & dd $24.3,8.1$ & \\
\hline & $\mathrm{CO}$ & & & 172.2 \\
\hline \multirow[t]{7}{*}{$N$-Me-Phe } & $\alpha \mathrm{CH}$ & $5.06 \mathrm{t}$ & 11.7 & 63.1 \\
\hline & $\mathrm{BCH}_{2}$ & $3.15 \mathrm{t}$ & 15.9 & 36.7 \\
\hline & & $2.95 \mathrm{t}$ & 11.5 & \\
\hline & $\mathrm{Ph} 1$ & & & 138.9 \\
\hline & $2-6$ & $7.0-7.2$ & & $127-130$ \\
\hline & $\mathrm{N}-\mathrm{CH}_{3}$ & 2.70 & 5.4 & 29.0 \\
\hline & $\mathrm{CO}$ & & & 169.4 \\
\hline \multirow[t]{7}{*}{ Met(-SO) } & $\alpha \mathrm{CH}$ & 4.42 & $\mathrm{~m}$ & 48.5 \\
\hline & $\beta \mathrm{CH}_{2}$ & 1.24 & $\mathrm{~m}$ & 23.6 \\
\hline & & 0.42 & br m & \\
\hline & $\gamma \mathrm{CH}$ & 2.54 & $\mathrm{~m}$ & 47.6 \\
\hline & $\mathrm{S}-\mathrm{CH}$ & 2.52 & s & 38.2 \\
\hline & $\mathrm{NH}$ & 8.15 & brs & \\
\hline & $\mathrm{CO}$ & & & 172.2 \\
\hline \multirow[t]{7}{*}{ Leu-2 } & $\alpha \mathrm{CH}$ & 3.87 & $\mathrm{~m}$ & 52.1 \\
\hline & $\beta \mathrm{CH}_{2}$ & 1.31 & $\mathrm{~m}$ & 40.6 \\
\hline & $\gamma \mathrm{CH}^{2}$ & 1.44 & $\mathrm{~m}$ & 24.1 \\
\hline & $\delta \mathrm{CH}_{3}$ & 0.57 & $\mathrm{~m}$ & 22.1 \\
\hline & & 0.76 & $\mathrm{~m}$ & 22.0 \\
\hline & NH & 7.38 & s & \\
\hline & $\mathrm{CO}$ & & & 173.5 \\
\hline \multirow[t]{8}{*}{ Lys } & $\alpha \mathrm{CH}$ & 4.13 & dd $12.2,4.9$ & 57.1 \\
\hline & $\mathrm{BCH}_{2}$ & 2.10 & $\mathrm{~m}$ & 29.4 \\
\hline & $\gamma \mathrm{CH}_{2}$ & 1.03 & $\mathrm{~m}$ & 29.1 \\
\hline & $\delta \mathrm{CH}_{2}$ & 1.26 & $\mathrm{~m}$ & 26.9 \\
\hline & $\varepsilon \mathrm{CH}_{2}$ & 3.57 & $\mathrm{~m}$ & 38.4 \\
\hline & & 2.65 & q $24.7,10.6$ & \\
\hline & $\mathrm{NH}$ & 6.89 & $\mathrm{~s}$ & \\
\hline & $\mathrm{CO}$ & & & 168.6 \\
\hline \multirow[t]{7}{*}{ Phe } & $\alpha \mathrm{CH}$ & 4.24 & $\mathrm{~m}$ & 57.4 \\
\hline & $\beta \mathrm{CH}_{2}$ & 3.00 & d 4.4 & 33.5 \\
\hline & $\mathrm{Ph} 1$ & & & 134.9 \\
\hline & $2-6$ & $7.0-7.2$ & & $127-130$ \\
\hline & $\mathrm{N}-\mathrm{CH}_{3}$ & 6.44 & $\mathrm{~s}$ & \\
\hline & $\mathrm{CO}$ & & & 174.0 \\
\hline & $\mathrm{CO}$ (ureido) & & & 156.7 \\
\hline
\end{tabular}

NMR, nuclear magnetic resonance.
In the ROESY spectrum, NOE correlations among 8-NH/6$\mathrm{NH}, 8-\mathrm{NH} / \mathrm{H} 14,24-\mathrm{NH} / \mathrm{H} 29$, and $\mathrm{H} 14 / \mathrm{H} 24$ supported the amino acids sequence (Fig. 5). A hydantoin (Hy) structure was also determined by HMBC experiment. Correlations from the $\alpha$-proton of Lys to both the carbonyl carbon of Phe and the ureido carbon, and from both $\alpha$ - and $\mathrm{NH}$ protons of Phe to the ureido carbon were observed. Based on these data, the planar structure of gamakamide-E was deduced (Fig. 6).

\section{Stereochemistry of gamakamide-E}

Acid hydrolysis of gamakamide-E, derivatization of the resultant amino acids with Marfey's reagent (Marfey, 1984), and subsequent HPLC analysis demonstrated L-stereochemistry of Met(O), $N$-Mephe and two Leus. No D- and L-Lys or D- and L-Phe peaks were observed, suggesting that the hydantoin was not hydrolyzed. Instead of peaks corresponding to Phe and Lys, two unidentified peaks supposedly generated by a phenylalanine-lysine hydantoin dipeptide (Phe-Lys-Hy) were observed at 108 and $111 \mathrm{~min}$. To determine the stereochemistries of Lys and Phe, four pairs of Phe-Lys-Hy were synthesized from the D- and L-lysine and D- and L-phenyl alanine and These amino acids were analysed by HPLC after hydrolysed $\left(6 \mathrm{~N} \mathrm{HCl}, 110^{\circ} \mathrm{C}\right)$, resulting in two peaks on chromatograms by Marfey's method (Horigome, 2000). Dipeptides (L-Phe-D-Lys and D-Phe-D-Lys) gave two peaks with retention times identical to those of gamakamide-E (108 and $111 \mathrm{~min}$ ), while D-Phe-L-Lys and L-Phe-L-Lys dipeptides gave two peaks at 109 and $110 \mathrm{~min}$. Thus, the retention times of the two peaks depended on the stereochemistry of Lys, and the $\alpha$ proton of phenylalanine in hydantoin was racemized under hydrolysis conditions. Peaks from dipeptides containing D-Lys matched the unidentified peaks from gamakamide-E. Therefore, the lysine in gamakamide-E was determined to be in the D-form. The chemical shift of the $\alpha$ proton of Phe in gamakamide- $\mathrm{E}$ in $\mathrm{CD}_{3} \mathrm{OD}$ agreed well with that of a methyl ester of L-Phe-D-Lys but not with that of D-Phe-D-Lys. Moreover, in the CD spectra of gamakamide-E, L-Phe-D-Lys, and D-Phe-D-Lys, both gamakamide-E and L-Phe-D-Lys but gave a negative Cotton effect at $220 \mathrm{~nm}$ in $\mathrm{MeCN}$, while D-PheD-Lys gave a positive Cotton effect at $220 \mathrm{~nm}$. These Cotton effects are thought to be generated from interactions between the aromatic Phe ring and the hydantoin. Therefore, the stereochemistry of Phe in gamakamide-E was determined to be the L-form. These results allowed us to determine the structure including the stereochemistry of gamakamide-E (Fig. 6).

Gamakamide-E was neither lethal to mice $(100 \mu \mathrm{g} / 20$ $\mathrm{g}$ mice ip) nor inhibited the growth of Aspergillus niger or Bacillus subtilis (Lee, 1995). Many cyclic peptides having strong and diverse biological activities have been isolated from sponges (Fusetani and Matsunaga, 1993) and ascidians (Davidson, 1993) but rarely from shellfish (Reese et al., 1996). The structure of gamakamide-E resembles the keramamides, anabaenopeptins and oscillamides isolated from sponges and 
cyanobacteria in having a ureido carbon and D-Lys in the molecule (Kobayashi et al., 1991; Harada et al, 1995; Marsh et al., 1997). Another bitter-tasting shelIfish incident occurred in Australia and was associated with a bloom of the diatom $R$. chunii (Parry et al., 1989). It is thus possible that gamakamide-E was produced by plankton, probably either a diatom or cyanobacterium, and accumulated through the food chain. However, no bloom was observed in the water at the time of the occurrence of the bitter-tasting oysters used in this study. Our future tasks will be to elucidate the biological activities and biogenetic origin of gamakamide-E.

\section{Acknowledgments}

We are grateful to Drs. Manabu Horikawa and Hideo Naoki, Suntory Institute for Bioorganic Chemistry for discussions. This work was financially supported by the Ministry of Education, Science, Sports and Culture, Japan (No. 07102002), CREST, Kakenhi (22404006) and Mikimoto Fund for Marine Ecology.

\section{References}

Davidson BS. 1993. Ascidians: producers of amino acid-derived metabolites. Chem Rev 93, 1771-1791.

Fusetani N and Matsunaga S. 1993. Bioactive sponge peptides. Chem Rev 93, 1793-1806.

Harada KI, Fujii K, Shimada T, Suzuki M, San H, Adachi K and Carmichael WW. 1995. Two cyclic peptides, anabaenopeptins, a third group of bioactive compounds from the cyanobacterium Anabaena flos-aqua NRC-525-17. Tetrahedron Lett 36, 1511-1514.
Hata M, Nakamura K and Fujiwara H. 1982. Brick-red coloration of oyster Crassostrea gigas. Nippon Suisan Gakkaishi 48, 975-979

Hata M, Matsumoto I, Itoh M, Hata M and Akashige S. 1987. Yellowish coloration of oyster Crassostrea gigas. Nippon Suisan Gakkaishi 53, 677-680.

Hatano M. Iida H, Seki K and Takahashi K. 1990. Occurrence of unacceptable taste and coloring of giant Pacific oyster. Nippon Suisan Gakkaishi 56, 1481-1484.

Horigome Y. 2000. Structure and synthesis of the bitter taste compound isolated from oyster, MS Thesis. Tohoku University, Tohoku, JP, pp. 31-38.

Kimura T. 1969. Study on greening of canned oyster. Bull Jpn Soc Sci Fish 35, 67-76.

Kobayashi J, Itagaki F, Shigemori H, Ishibashi M, Takahashi K, Ogura M, Nagasawa S, Nakamura T, Hirota H, Ohta $\mathrm{T}$ and Nozoe S. 1991. Keramides B approx D, novel peptides from the Okinawan marine sponge, Theonella sp. J Am Chem Soc 113, 7812-7813.

Lee JS. 1995. Isolation and some properties of bitter taste compounds from cultured oyster, Crassostrea gigas. Bull Korean Fish Soc 28, 98-104.

Marfey P. 1984. Determination of D-amino acids. II. Use of a bifunctional reagent 1,5-difluoro-2,4-di nitrobenzene. Carlsberg Res. Commun 49, 591-596.

Marsh IR, Bradly M and Teague SJ. 1997. Solid-phase total synthesis of oscillamide Y and analogues. J Org Chem 62, 6199-6203.

Parry GD, Langdon JS and Huisman JM. 1989. Toxic effects of a bloom of the diatom Rhizosolenia chunii on shellfish in Port of Phillip Bay, Southeastern Australia, Mar Biol 102, 25-41.

Reese MT, Gulavita NK, Nakao Y, Haean MT, Yoshida WY, Coval SJ and Scheuer PJ. 1996. Kulolide: A cytotoxic depsipeptide from a Cephalaspidean Philinopsis speciosa. J Am Chem Soc 118, 1108111084. 